\title{
Detection of anti-Leptospira antibodies in domestic captive primates from Acre, Brazil
}

\section{Deteç̧ão de anticorpos anti-Leptospira spp. em primatas provenientes de cativeiro doméstico no Acre-Brasil}

\author{
Luciana dos Santos Medeiros ${ }^{1 *}$; Soraia Figueiredo de Souza ${ }^{1}$; \\ Yuri Karaccas de Carvalho'; Vânia Maria França Ribeiro'; \\ Gabriel Mendes de Souza Martins'; Walter Lilenbaum ${ }^{3}$
}

\begin{abstract}
Because the Wild Animals Screening Center (CETAS) focuses intensely on restoration and maintenance of primate health and diversity in the Amazon region, detection of potential threats to animal health is crucial. In this view, neglected infections such as leptospirosis are of particular interest. In this report, we have studied the seroreactivity of anti-Leptospira antibodies from primate blood samples collected at CETAS between September 2011 and September 2012. Of the 14 animals investigated by the microscopic agglutination test using live antigens, five (35.7\%) were reactive against serovars Celledoni (1), Hebdomadis (1), Icterohaemorrhagiae (2), and Sejroe (1). The results indicate that it is important to identify the contact of these animals with possible pathogens in order to ensure reintroduction of healthy animals into the wild and further understand the disease epidemiology in animals under captivity, gathering, and voluntary surrender of domestic captivity in Acre, Brazil.
\end{abstract}

Key words: Domestic captivity. Leptospirosis. Primates. Zoonosis.

\section{Resumo}

Tento em vista a importância do Centro de Triagem de Animais Silvestres (CETAS) no estado do Acre para restauração e manutenção da saúde e diversidade de primatas da Região Amazônica, é necessária a detecção de possíveis ameaças à saúde animal, em especial infecções negligenciadas como a leptospirose. Neste sentido estudou-se a ocorrência de sororreatividae anti-Leptospira sp., pela técnica da soroaglutinação microscópica com antígenos vivos, em primatas recolhidos pelo CETAS no período de setembro/2011 a setembro/2012. Dos 14 animais testados, cinco (35,7\%) foram reativos aos sorogrupos Celledoni (1), Hebdomadis (1), Icterohaemorrhagiae (2) e Sejroe (1). Neste sentido é importante identificar o contato dos animais de triagem com agentes patogênicos a fim de garantir a reintrodução de animais saudáveis e conhecer a epidemiologia da enfermidade em animais provenientes de apreensão, recolhimento e entrega voluntária de cativeiros domésticos no Acre, Brasil.

Palavras-chave: Cativeiro doméstico. Leptospirose. Primatas. Zoonose.

\footnotetext{
${ }^{1}$ Profs., Universidade Federal do Acre, UFAC, Rio Branco, AC, Brasil. E-mail: lusmedeiros@yahoo.com.br; soraiasouza@yahoo. com; ykaracas@yahoo.com.br; vania.rib@uol.com.br

2 Discente de Doutorado, Programa de Pós-Graduação em Medicina Veterinária: Clínica e Reprodução Animal, Universidade Federal Fluminense, UFF, Niterói, RJ, Brasil. E-mail: gmartins@id.uff.br

3 Prof., UFF, Niterói, RJ, Brasil. E-mail: mipwalt@vm.uff.br

* Author for correspondence
} 
Leptospirosis is a zoonosis that affects domestic and wild animals (exotics and natives) and has a wide geographic distribution. Diagnosis of leptospirosis in primates is difficult in comparison to other animal species because of less evident clinical symptoms and lesions and the short time span of antibody response (SCARCELLI et al., 2003). Despite the limitations of serological diagnosis of leptospirosis, microscopic agglutination test (MAT) is the recommended method (OIE, 2012).

Although anti-Leptospira antibodies have often been reported in native free-living wild animals, relevant literature on captive wild animals is scarce. The few studies conducted on captive animals are specific to the habits and habitat of the studied species and show a great variability in both antibody titers and serovars associated with infection (MINETTE, 1966; LILENBAUM et al., 2002, 2005; PINNA et al., 2012; MORENO-BEAS et al., 2015). Although rare, fatal cases of leptospirosis in captive primates have been reported (PEROLAT et al., 1992; LUNA-ALVAREZ et al., 1996). The presence of anti-Leptospira antibodies in captive primates is of significant concern primarily with respect to the reproduction and maintenance of endangered species, their quality of life, and their potential re-introduction into their natural habitat.

If the captured animals are not on the list of endangered species, they are preferably raised in zoos, IBAMA-registered conservation units, or research centers depending on their degree of domestication. The animals are released at an appropriate time according to specific management programs for the different species (IBAMA, 2009). In such cases, if the primates in captivity are infected by strains of Leptospira, there is a high probability of introducing these new urban pathogens into the wild environment thereby threatening the diverse native population (PINNA et al., 2012).

Given the pioneering work of Centro de Triagem de Animais Silvestres (Wild Animals
Screening Center - CETAS), Acre, Brazil, in restoring and maintaining the health and diversity of non-human primates in the Amazon region, it is essential to identify possible threats to animal health, particularly neglected infections such as leptospirosis. Therefore, this study on antiLeptospira reactivity was conducted with serum samples collected by CETAS from domestic captive primates in the state of Acre.

Blood samples were collected from 14 domestic captive primates, which were either voluntarily delivered to official services or sent to CETAS between September 2011 and September 2012. The samples were collected in vacuum tubes by puncturing the jugular vein of the animals sedated by intramuscular administration of $1 \%$ acepromazine $(0.1 \mathrm{mg} / \mathrm{kg})$ followed by $5 \%$ ketamine chlorhydrate $(11 \mathrm{mg} / \mathrm{kg})$ and diazepam $(0.25 \mathrm{mg} / \mathrm{kg})$ (ALVES et al., 2000). Blood samples were transported to the laboratory under cold conditions, centrifuged at $16,000 \times \mathrm{g}$. for 10 minutes, and the serum was frozen in $1.5 \mathrm{~mL}$ plastic micro tubes at $-20{ }^{\circ} \mathrm{C}$ for further analysis (OIE, 2012).

Serological diagnosis of leptospirosis was performed by serum agglutination with live antigens (MAT) and evaluated under a microscope equipped with a dark field condenser, according to the technical recommendation by OIE. Totally, 23 serovars of Leptospira (Australis, Autumnalis, Bataviae, Bratislava, Canicola, Castellonis, Celledoni, Copenhageni, Cynopteri, Djasiman, Gripotyphosa, Guaricura, Hardjobovis, Hebdomadis, Icterohaemorrhagiae, Javanica, Panama, Pomona, Pyrogenes, Sarmin, Sejroe, Wolffi, and Tarassovi) representing 16 serogroups were used as antigens. The samples that agglutinated at 1:50 dilution were further tested against the reactive antigen using a 2-fold serial dilution. The reaction titer with 50\% agglutinated Leptospira corresponded to the reciprocal of the highest dilution of serum. A minimum titer of 100 was considered as reactive (OIE, 2012). 
Of the 14 animals examined, five $(35.7 \%$ of the sample set) were reactive to at least one serogroup (Table 1). As shown in Table 2, these reactive serum samples were distributed between serogroups Celledoni (1), Hebdomadis (1), Icterohaemorrhagiae (2), and Sejroe (1).

Table 1. Serological diagnosis of leptospirosis in the 14 domestic captive primates from Acre, Brazil.

\begin{tabular}{ccccc}
\hline \multicolumn{5}{c}{ Anti-Leptospira antibody titer } \\
\hline Species & $<100$ & 100 & $>=200$ & Total \\
Alouatta seniculus & 4 & - & - & 4 \\
Callicebus moloch & - & 1 & - & 1 \\
Cebus albifrons & 2 & 2 & - & 4 \\
Cebus apela & 2 & 1 & - & 3 \\
Lagothrix sp. & 1 & 1 & - & 2 \\
& 8 & 5 & - & 14 \\
\hline
\end{tabular}

Table 2. Serological identification of Leptospira serogroups in the Leptospira-positive domestic captive primates.

\begin{tabular}{ccccc}
\hline Animal & Celledoni & Hebdomadis & Icterohaemorrhagiae & Sejroe \\
\hline Cebus albifrons & - & 100 & - & - \\
Cebus albifrons & - & $<100$ & $<100$ & 100 \\
Cebus apela & - & - & 100 & - \\
Lagothrix sp. & - & - & 100 & - \\
Callicebus moloch & 100 & - & - & - \\
\hline
\end{tabular}

The presence of anti-Leptospira antibodies in captive primates has been previously reported (LILENBAUM et al., 2005; PINNA et al., 2012) and the possible introduction of new Leptospira strains into natural habitats was highlighted by underlining the high percentage of reactive animals, especially to Icterohaemorrhagiae, being susceptible to leptospirosis after reintroduction (PINNA et al., 2012). Serum reactivity for this serogroup was observed in this study as well; the primates may have been exposed at their facility owing to the constant presence of urban rodents, which are the main reservoirs of this serotype. Presence of food particles on the ground of these facilities has been previously reported as an important factor in promoting the proximity between urban rodents and primates (LILENBAUM et al., 2005). The housing and living conditions at the zoos and research centers do not allow regular maintenance of captive animals in isolation from the wild and synanthropic animals, which in turn facilitates exposure to Leptospira, especially in terrestrial animals (PEROLAT et al., 1992; SCARCELLI et al., 2003; PIMENTEL et al., 2009).

Unlike other studies (LILENBAUM et al., 2005; PINNA et al., 2012), in this study the animals were assessed at the moment they were received at the screening center. Thus, presumably, these animals were representative of the environment they lived in prior to capture. Since the animals were originally from domestic captivity facilities located in both urban and rural areas, the higher variation observed in the serum reactivity could represent the wide and unknown occurrence of leptospirosis in animals coming from different environments. 
Reservoirs and maintenance hosts of Lepstospira sp. are diverse and include domestic and wild animals (exotics and natives). A notable characteristic of this pathogen is that each serovar is host-specific and believed to adapt to that particular animal species (PICARDEAU, 2013). The wide variety of antibodies observed against the different serogroups in this study could be indicative of the different antigenic variants (strains) circulating through primates that are potential reservoirs of the different lineages of Leptospira.

In conclusion, this study reports the presence of anti-Leptospira agglutinins in domestic captive primates captured by CETAS, in the state of Acre, Brazil. Thus, active surveillance of the collected animals at the moment of their reception is recommended.

\section{Acknowledgments}

The authors acknowledge the Conselho Nacional de Desenvolvimento Científico e Tecnológico - CNPq for granting a PIBIC scholarship and the Instituto Brasileiro do Meio Ambiente e dos Recursos Naturais Renováveis - IBAMA for their approval of the project under protocol 02002002213 / 11-53. We would also like to thank Dr. Joseline de Oliveira Guimarães (IBAMA) and Dr. Elaine Oliveira (CETAS) for their support.

\section{References}

ALVES, S. F.; LEFEBVRE, R. B.; PROBERT, W. Amino acid sequences of proteins from Leptospira serovar Pomona. Memórias do Instituto Oswaldo Cruz, Rio de Janeiro, v. 95, n. 4, p. 503-504, 2000.

INSTITUTO BRASILEIRO DO MEIO AMBIENTE E DOS RECURSOS NATURAIS - IBAMA. CETAS. 2009. Disponível em: <http://www.ibama.gov.br/fauna/ cetas.php>. Aceso em: 07 nov. 2011.

LILENBAUM, W.; MONTEIRO, R. V.; RISTOW, P.; FRAGUAS, S.; CARDOSO, V. S.; FEDULLO, L. P. L. Leptospirosis antibodies in mammals from Rio de Janeiro Zoo, Brasil. Research in Veterinary Science, Oxford, v. 73, n. 3, p. 319-321, 2002.
LILENBAUM, W.; VARGES, R.; MORAES, I. A.; FERREIRA, A. M. R.; PISSINATTI, A. Leptospiral antibodies in captive Lion tamarins (Leontopithecus sp.) in Brazil. The Veterinary Journal, Liverpool, v. 169, n. 3, p. 462-464, 2005.

LUNA-ALVAREZ, M. A.; MOLES-CERVANTES, L. P.; TORRES-BARRANCA, J. I.; GUAL-SILL, F. Investigación serologica de leptospirosis en fauna silvestre mantenida en cautiverio en el zoologico de Chapultepec de la ciudad de Mexico. Veterinaria Mexico, Cidade do México, v. 27, n. 3, p. 229-234, 1996.

MINETTE, H. P. Leptospirosis in primates other than man. The American Journal of Tropical Medicine and Hygiene, Los Angeles, v. 15, n. 2, p. 190-198, 1966.

MORENO-BEAS, E.; ABALOS, P.; HIDALGOHERMOSO, E. Seroprevalence of nine Leptospira interrogans serovars in wild carnivores, ungulates, and primates from a zoo population in a metropolitan region of Chile. Journal of Zoo and Wildlife Medicine, Washington, v. 46, n. 4, p. 774-778, 2015.

PEROLAT, P.; POINGT, J. P.; VIE, J. C.; JOUANEAU, C.; BARANTON, G.; GYSIN, J. Occurrence of severe leptospirosis in a breeding colony of squirrel monkeys. American Journal of Tropical Medicine and Hygiene, Los Angeles, v. 46, n. 5, p. 538-545, 1992.

PICARDEAU, M. Diagnosis and epidemiology of leptospirosis. Médecine et Maladies Infectieuses, Grenoble, v. 43, n. 1, p. 1-9, jan. 2013.

PIMENTEL, J. S.; GENNARI, S. M.; DUBEY, J. P.; MARVULO, M. F. V.; VASCONCELLOS, S. A.; MORAIS, Z. M.; SILVA, J. C. R.; EVÊNCIO NETO, J. Inquérito sorológico para toxoplasmose e leptospirose em mamíferos selvagens neotropicais do Zoológico de Aracaju, Sergipe. Pesquisa Veterinária Brasileira, Seropédica, v. 29, n. 12, p. 1009-1014, 2009.

PINNA, M. H.; MARTINS, G.; PINHEIRO, A. C.; ALMEIDA, D. S.; ORIÁ, A. P.; LILENBAUM, W. Detection of anti-Leptospira antibodies in captive nonhuman primates from Salvador, Brazil. American Journal of Primatology, Hoboken, v. 74, n. 1, p. 8-11, jan. 2012.

SCARCELLI, E.; PIATTI, R. M.; FEDULLO, J. D. L.; SIMON, F.; CARDOSO, M. V.; CASTRO, V.; MIYASHIRO, S.; GENOVEZ, M. E. Leptospira spp detection by polymerase chain reaction (PCR) in clinical sample of captive Black-capped Capuchin Monkey (Cebus apella). Brazilian Journal of Microbiology, São Paulo, v. 34, n. 2, p. 143-146, 2003.

WORLD ORGANIZATION FOR ANIMAL HEALTH OIE. Manual of diagnostic tests and vaccines for terrestrial animals. Paris: Office International des Epizooties, 2012. 